Ethiopian Journal of Environmental Studies \& Management 9(3): 255 - 266, 2016.

ISSN:1998-0507

doi: http://dx.doi.org/10.4314/ejesm.v9i3.1

Submitted: July 28, 2015

Accepted: April 15, 2016

\title{
RAPID SURVEY OF DRAGONFLIES (INSECTA: ODONATA) OF KRIBI FOREST AND CAMPO MA'AM NATIONAL PARK, SOUTHERN CAMEROON
}

\author{
*ADU, B.W., 1 OGBOGU S.S. ${ }^{2}$ AND AKINDELE, E.0. ${ }^{2}$ \\ ${ }^{1}$ Department of Biology, Federal University of Technology Akure, Ondo State, Nigeria \\ ${ }^{2}$ Department of Zoology, Obafemi Awolowo University, Ile-Ife
}

\begin{abstract}
A five day survey was carried out to assess the odonate fauna associated with the riverine sections of two forests (Kribi Forest and Campo Ma'am National Park) of southern Cameroon. The primary objective of the study was to determine the species composition and community structure of the odonate fauna occurring in the forests. The goal is to infer the health status of the two forests. Three study sites were selected, one in each of the main water bodies in the forests (Rivers Kienke and Linde in Kribi forest, and River Bitande in Campo Ma'am National Park). All the specimens collected were identified to the lowest taxonomic level. A total of one hundred and ninety four (194) individuals of Odonata were collected in the forests comprising 10 families, 24 species of Anisoptera and 30 species of Zygoptera. Anthropogenic activities were less prevalent at Campo Ma'am National Park, an area in which all the 10 families were incidentally recorded. The community structure of the southern forest revealed that only River Bitande with Shannon-Wiener diversity index $\left(H^{\prime}\right)$ of 3.80 was having a stable environmental condition. Others were close to stable condition (River Kienke $H^{`} 2.99$ and River Linde $H^{\prime}$ 2.95) with mild disturbance caused by human activity. Simpson index range $(0.94-0.98)$ at the three study sites revealed that the vegetation was matured and stable. The distribution of dragonflies and damselflies revealed a stable environment (Evenness $0.90-0.95$ ). Kribi Forest appears to be more impacted by anthropogenic activities as fewer (six) families were recorded there. The relative distribution of the species in the two forest ecosystems seemed to have some relationship with human interference therein.
\end{abstract}

Key Words: Damselfly, Dragonfly, Diversity, Forest, River

\section{Introduction}

Tropical countries especially in subSaharan Africa are facing problem of deforestation occasioned by increased human activities and poor management of forest resources (Smith et al., 2009). This has resulted in loss of some flora and fauna that are endemic to tropical forest ecosystems. Practices such as felling of trees, point source discharge, damming and channelization of streams and rivers have resulted in the opening up of forests and degradation of the water bodies (Smith et al., 2009).

Channelization of rivers and streams affects the velocity of water leading to deposition of silt and consequently change in their substrate composition

*Corresponding Author: Adu, B.W.

Email: williamsadubabs@yahoo.com 
(Adu, et al., 2014). This change is hazardous to the wellbeing of odonate fauna both in water and within riparian forest vegetation. These unhealthy conditions usually result in habitat shift or death of dragonflies and damselflies, especially those with narrow niche (Adu and Ogunjobi, 2014). Odonate fauna with broad niche and mostly the ubiquitous can cope considerably in disturbed habitat (Clausnitzer, 2006). They are also good colonizers of temporary environment and some are known to be good indicators of polluted freshwater and terrestrial environments (Corbet, 1999).

Vegetation architecture plays important role in regulating the distribution and assemblage of Odonata species (Korkeamaki and Suhonen, 2002). Therefore, a depleted forest will be too open for shade-lovers, who might have been killed or migrated out of the environment. River ecosystems especially the adjacent riparian vegetation usually have a high assemblage of Odonate fauna. Streams, freshwater swamps and peat swamps are known to be rich in dragonflies and damselflies (Che Salmah et al., 2005). Although Odonata occurs in almost every form of freshwater ecosystem, microhabitats with high heterogeneity of vegetation are believed to be the primary factor determining their composition, diversity and distribution (Watanabe et al., 2004).

Dragonflies and damselflies are sensitive to anthropogenic activity (Clark and Samways, 1996; Stewart and Samways, 1998). The two areas selected for this study (Kribi Forest and Campo Ma'am National Park) have heterogeneous vegetation, although they are of different status (unprotected and protected forests respectively). It was hypothesized that the two forests would have diverse forms of anthropogenic activities which could influence their local flora and fauna. It was further hypothesized that, since the two forests were experiencing different levels of human disturbance, they would differ in terms of Odonata species composition and community structure. This study was thus aimed at describing the health status of the two forest ecosystems based on the species composition and community structure of dragonflies and damselflies in the forests.

Studying Odonata of southern Cameroon dates back to 1884 (Vick 2003) when the Germans took over the coastal part of Duala territory (Mbuagbaw et al., 1987). Series of research works on Odonata have been carried out in the country ever since. Contributions of odonatologists like Karsch (1890) laid the foundation of the study of dragonflies in Cameroon. Pinhey (1962, 1964, and 1974) gave detailed records of Odonata from Fernando Po, Malende, Koto Barombi and Nyasoso. Recent works on dragonflies of southern Cameroon include that of Vick (2003), which provided a checklist of the Odonata of the southwestern Province of Cameroon and biodiversity assessment of the Odonate fauna of the Takamanda Forest Reserve. Other scholarly works include Chelmick (1999, 2001) who worked on the larvae of a member of Aeshnidae. The contributions of these scholars have revealed that southern Cameroon forests are very rich in Odonata. This particular study was a quick and brief assessment of two forests in southern Cameroon, viz Kribi Forest and Campo Ma'am National Park. According to Dijkstra (2007), a rapid 
survey of a forest is able to give a fair picture of the local diversity of Odonata within a short period of time. Although previous scholars agreed that the forests are hotspots of Odonate fauna, data on the local faunal composition of Odonata in the forests are lacking.

This paper is a product of the fieldwork carried out during a brief visit to the forests. Although it was a rapid assessment of Odonate fauna in the forests, it was meant to supplement already known information on Odonata of Cameroon in general and of the forests in particular. Besides, the effect of climate change and human activities prevailing in sub-Saharan forests, which could have altered composition, distribution and species diversity of odonate fauna in the forest, necessitated the need for an assessment of the current status forests.

\section{Materials and Methods Study Site}

Two forests in Southern Cameroon were surveyed with the intention of identifying odonate species inhabiting the forests. These two forests, like most forests in sub-Saharan Africa, are subjected to degradation owing to anthropogenic activities. Human activities in the two forests include farming; logging and construction work especially in Kribi forest. These activities were however minimal at the Campo Ma'am National Park due to strict compliance with government forest conservation and management policies. Nevertheless, limited logging was allowed in some part of the park. Subsistence farming was observed at the camps adjacent to the forest. Three study sites were established in the two forests: two in Kribi forest and one site at Campo-Ma'am National Park. Table 1 presents the Geo- reference coordinate of the three study sites while Figure 1 presents the map of south Cameroon forest.

Table 1: Geo-reference coordinates of the three study sites at Kienke, Linde, and Bitande Rivers.

\begin{tabular}{lll}
\hline Study Site & Location & Geo-Reference Coordinate \\
\hline River Kienke & Kribi Forest & $02^{\circ} 28^{`} 12-02^{\circ} 28^{`} 56 \mathrm{~N}, 09^{\circ} 51^{\prime} 28-09^{\circ} 51^{`}$ \\
River Linde & Kribi Forest & $47^{\prime} \mathrm{E}$ \\
River Bitande & $02^{\circ} 25^{\prime} 33-02^{\circ} 26^{\prime} 08 \mathrm{~N}, 09^{\circ} 51^{\prime} 48-09^{\circ} 52^{\prime} 06^{\prime} \mathrm{E}$ \\
& Campo Ma'am & $02^{\circ} 21^{\prime} 42-02^{\circ} 21^{\prime} 58 \mathrm{~N}, 09^{\circ} 55^{\prime} 58-09^{\circ} 56^{\prime} 10^{\prime} \mathrm{E}$ \\
\hline
\end{tabular}




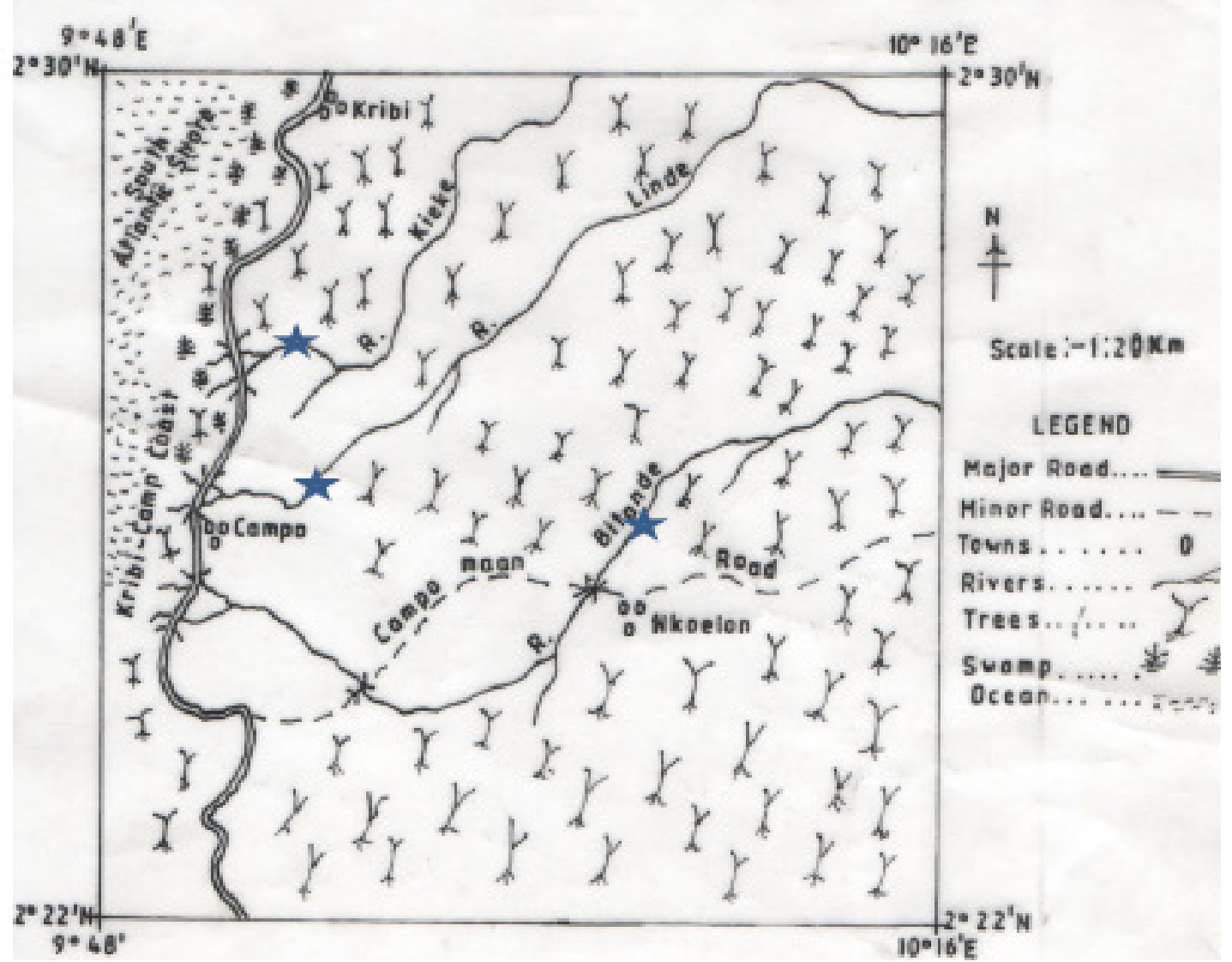

Figure 1: Map of Southern Cameroon Forest Reserve. The Stars ( $t)$ on the map indicate the three study sites

\section{Collection, Preservation and}

\section{Identification of Specimens}

Samples of adult dragonflies and damselflies were caught using a sweep net. The sampling was carried out in the two forests between 9.00 am and 4.00 pm. The survey lasted for 5 days $\left(10^{\text {th }}\right.$ $14^{\text {th }}$ June, 2008). Kribi Forest was surveyed from $10^{\text {th }}$ to $12^{\text {th }}$ of June and Campo-Ma'am forest surveyed on $13^{\text {th }}$ and $14^{\text {th }}$ of June. All the specimens collected were kept in small triangular envelopes. Males and females caught in tandem were placed together inside one envelope and then labeled. Adult specimens were preserved by placing each catch in a triangular envelope and then immersing them in acetone. The specimens were allowed to remain inside acetone for a minimum of 12 hours, after which they were dried on tissue paper in open air and then kept in cellophane envelopes. All specimens collected were deposited in the National Museum of Natural History Naturalis, Leiden, Netherlands. Identification of all the samples collected was carried out by an odonatological expert in Cameroon.

\section{Data Analysis}

Species richness of the three study sites was determined using diversity indices which include Shannon-Wiener index $\left(\mathrm{H}^{`}\right)$ Margalef index $d$ Simpson's Dominion index (C) and Evenness E. Simple descriptive statistic like percentage was also used in the analysis of the data collected in the study. 


\section{Results}

Table 2 presents the relative distribution of odonate species recorded in the three study sites during the fiveday survey. A total of 194 individuals of dragonflies and damselflies were collected at the sites during the period. The collected samples belonged to 54 species in ten families. Six out of the ten families were zygopterans (Lestidae, Platycnemididae, Protoneuridae, Coenagrionidae, Chlorocyphidae and Calopterigidae) while the rest were anisopterans (Libellulidae, Gomphidae,Corduliidae and Aeshnidae). Only one species each of Aeshnidae (Gynacantha bullata) and Lestidae (Lestes uncifer) were collected in this study. Zygoptera was the dominant suborder with 30 species represented, while Anisoptera had 24 species.

Figures 2 and 3 show the qualitative and quantitative contributions of each odonate family in the three study sites. A total of six families each were recorded in Rivers Kienke and Linde, while all the ten families were recorded in River Bitande. Libellulidae (Anisoptera) was the family with the largest number of species in the three sites, while Lestidae and Aeshnidae were both represented by only one species each. All species of Chlorocypha sampled in this study were represented in all the study sites except Chlorocypha neptunus which was not found in Kribi forest (Rivers Kienke and Linde). Two species of Pseudagrion ( $P$. camerunensis and P.serrlatun) were also found present in all the sites. Other dragonflies and damselflies found common in all the sites were Elattoneura pruinosa, Othetrum brachiale, Othetrum stemmale and Trithemis arteriosa. Quantitatively, the most dominant families in the three study sites were Libellulidae, Chlorocyphidae and Coenagrionidae.

Table 2: Relative distribution of species of Odonata in Kribi Forest and Campo Ma'am National Park, Southern Cameroon (June, 2008)

\begin{tabular}{|c|c|c|c|}
\hline \multirow[t]{3}{*}{ Taxa } & \multicolumn{3}{|l|}{ Study Sites } \\
\hline & \multicolumn{2}{|l|}{ Kribi Forest } & $\begin{array}{l}\text { Campo-Ma'am } \\
\text { National Park }\end{array}$ \\
\hline & R. Kienke & R. Linde & R. Bitande \\
\hline Aeshnidae & & & \\
\hline $\begin{array}{l}\text { Gynacyanta bullata Karsch, } 1891 \\
\text { Calopterygidae }\end{array}$ & 0 & 0 & 1 \\
\hline Phaon camerunensis Sjostedt 1900 & 1 & 0 & 0 \\
\hline Phaon iridipensis (Burmeister, 1839) & 1 & 0 & 3 \\
\hline Sapho orichalcea McLachlan 1969 & 0 & 1 & 2 \\
\hline Sapho gloriosa McLachlan in Selys, 1873 & 0 & 0 & 2 \\
\hline Saphon ciliate (Fabricius, 1781) & 0 & 0 & 2 \\
\hline Umma longistigma (Selys,1869) & 1 & 2 & 3 \\
\hline Chlorocyphidae & & & \\
\hline Chlorocypha centripunctata Gambles, 1975 & 1 & 2 & 3 \\
\hline Chlorocypha cancellata (Selys, 1879) & 1 & 3 & 2 \\
\hline Chlorocypha curta (Hagen in Selys, 1853) & 2 & 2 & 3 \\
\hline Chlorocypha cyanifrons (Selys, 1873) & 2 & 3 & 3 \\
\hline Chlorocypha glauca (Selys, 1879) & 2 & 2 & 3 \\
\hline $\begin{array}{l}\text { Chlorocypha neptunus (Sjostedt, 1899) } \\
\text { Coenagrionidae }\end{array}$ & 0 & 0 & 2 \\
\hline Africallagma vaginale (Sjostedt, 1917) & 2 & 0 & 2 \\
\hline
\end{tabular}


Agriocnemis maclachlani Sjostedt, 1877

Agriocnemis forcipata Le Roi 1915

Pseudagrion kersteni (Gerstacker,1869)

Psuedagrion camerunense Karsch, 1899

Pseudagrion melanicterum Sels, 1876

Pseudagrion rissi Schmidt in Ris, 1936

Pseudagrion serrulatum Karsch, 1894

Corduliidae

Phyllomacromia contumax Selys, 1879

Phyllomacromia overlaeti (Schouteden,1934)

Phyllomacronia paula (Karsch 1892)

Gomphidae

Diastatomma tricolour (Palisot de Beauvois, 1805)

Neurogomphus agilis (Martins, 1908)

Microgomphus camerunensis Longfield, 1951

Protoneuridae

Chlorocnemis eisentrauti Pinhey, 1974

Chlorocnemis abbotti (Calvert, 1896)

Chlorocnemis nigripes Selys, 1886

Elattoneura balli Kimmins, 1938

Elattoneura lliba Legrand, 1985

Elattoneura josemorai Compte Sart, 1964

Elattoneura pruinosa (Selys, 1886)

Platycnemididae

Platycnemis rufipes (Selys1886)

Mesocnemis singularis Karsch, 1891

Lestidae

Lestes uncifer (Karsch, 1899)

Libellulidae

Orthetrum abbotti Calvert,1892

Orthetrum brachiale (Palisot de Beauvois, 1805)

Ortherum juliaKirby, 1900

Orthetrum microstigmaRis, 1911

Orthetrum stemmale(Burmeister, 1839)

Neodythemis gorilla Pinhey, 1961

Pantala flauescens(Fabricius, 1798)

Palpopleura ivera

Palpopleura lucia(Drury, 1773)

Palpopleira portia (Drury, 1773)

Trithemis aenea Pinhey, 1961

Trithemis annulata(Palisot de Beauvois, 1805)

Trithemis arteriosa (Burmeister, 1839)

Trithemis dichroa Karsch, 1893

Trithemis groutiPinhey, 1961

Trithemis hartwigPinhey, 1970

Trithemis tropicana Fraser, 1953

Number of species

Total Individuals 
Rapid Survey of Dragonflies (Insecta: Odonata) of Kribi Forest................ADU et al.

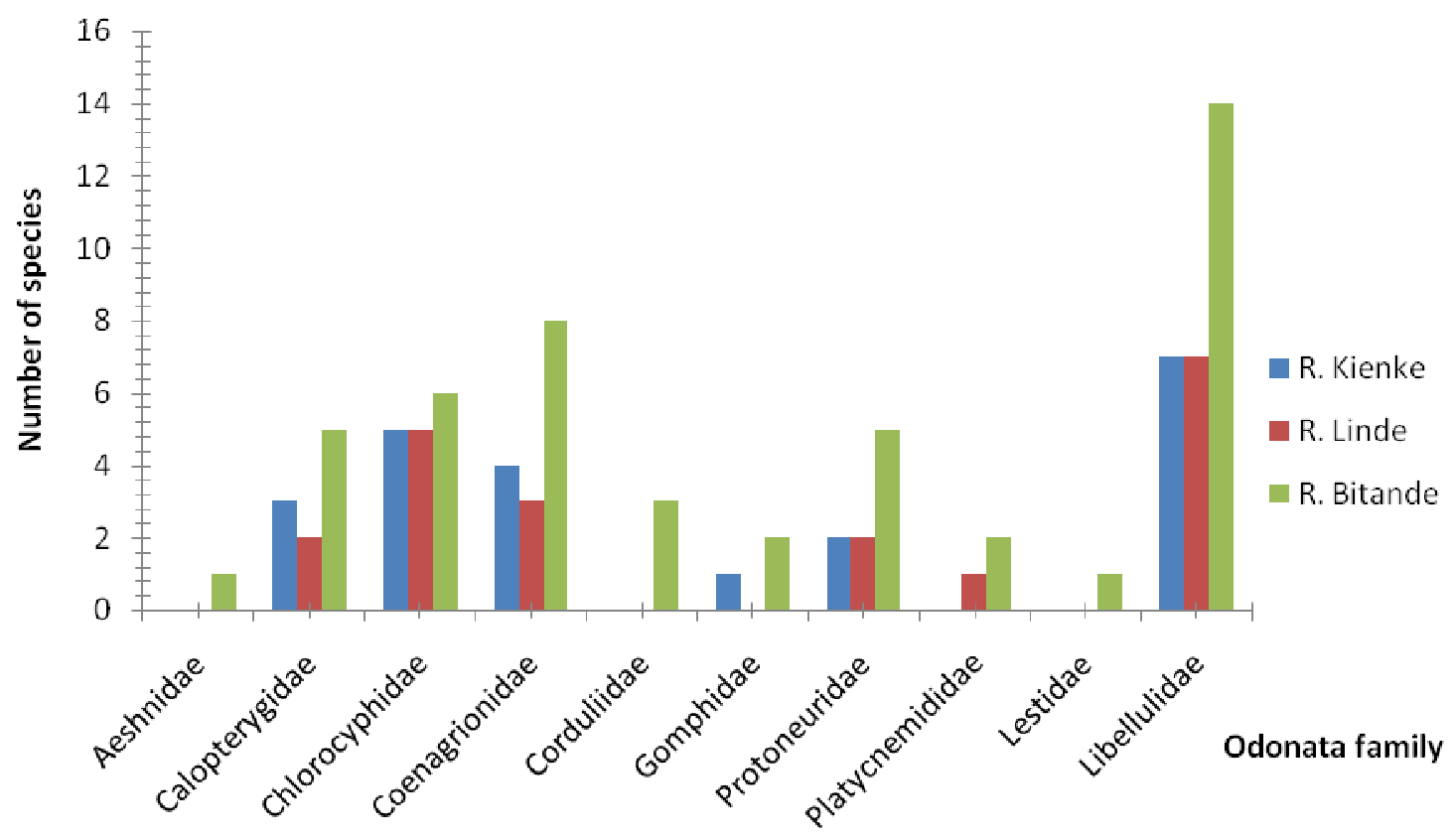

Figure 2: Abundance of Odonata species in Kribi Forest and Campo-Ma'am National Park, Southern Cameroon

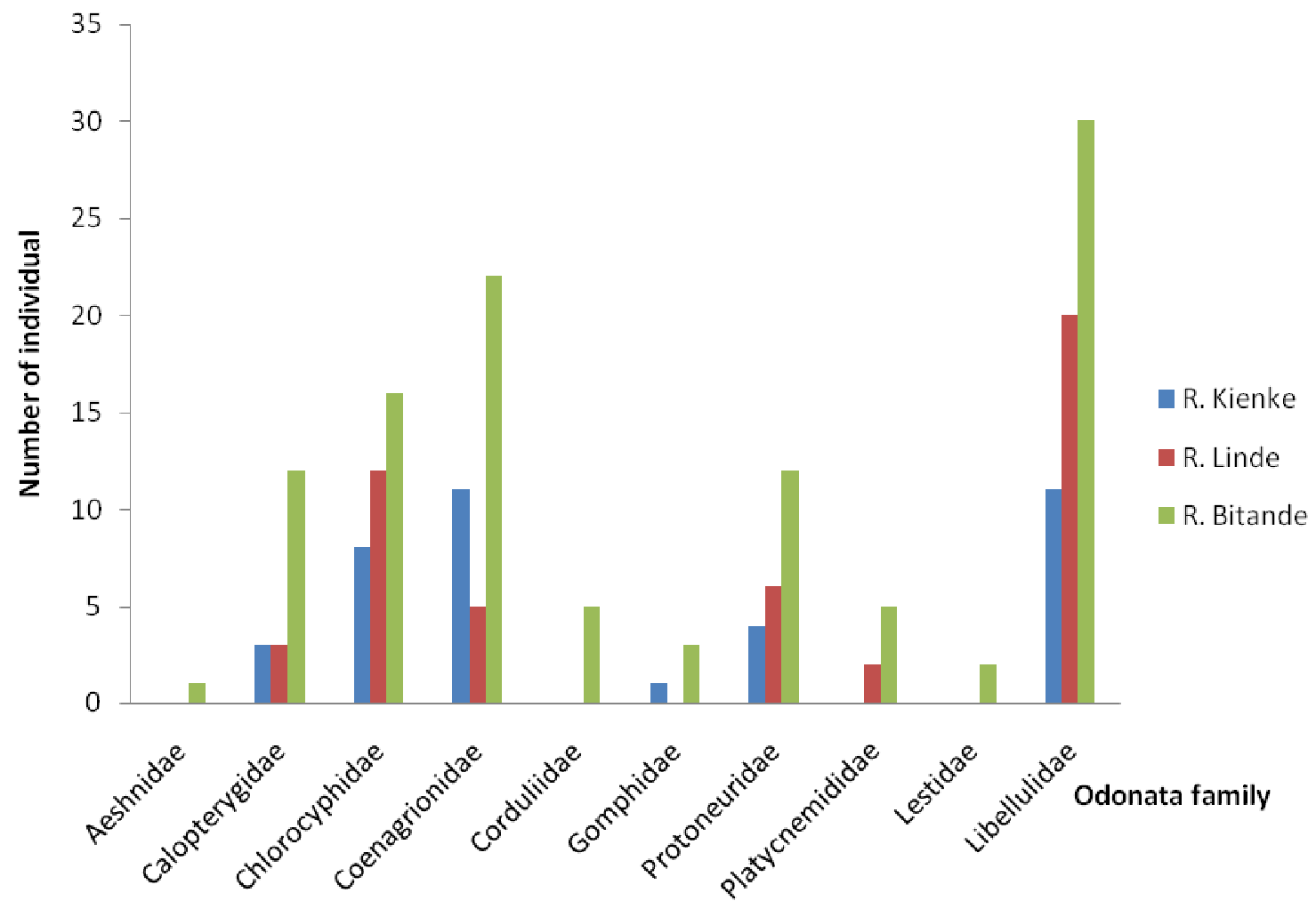

Figure 3: Number of individuals of Odonata families sampled in Kribi Forest and Campo-Ma' am National Park, southern Cameroon 
The community structures of Odonata fauna in the forests are presented in Table 2. River Bitande had the highest number of species (47) followed by River Kienke (22 species) and River Linde (20 species). The highest abundance of Odonata was recorded at Campo Ma'am National Park (River Bitande), and this was significantly higher $(\mathrm{p}<0.001)$ than the other two sites. Shannon-Weiner (H'), Simpson (1-D) and Margalef (d) indices indicated that Campo-Ma'am National Park (River Bitande) recorded the highest diversity of Odonata, while River Linde (Kribi Forest site) recorded the lowest. Evenness of species was lowest at River Kienke (Kribi Forest site) and highest at River Bitande (Campo-
Ma'am National Park site).Species richness of the three study sites was quite healthy since all of the study site have Shannon-Wiener diversity index of closer 3.00 , which is above 2.00 (a value characterized with moderate polluted condition). Shannon-Wiener index of 3.00 signifies stable environmental condition (Sarmistha et al., 2009).

Simpson dominance index is also very close to 1.0 which shows the two forests is matured and in stable environmental condition (see table 3). The evenness values were close to 1.0 in the entire study site which shows that the species in the forest were evenly distributed (Table 3).

Table 3: Community structure of Odonate fauna in Kribi Forest and Campo-Ma'am National Park, Southern Cameroun (June 2008)

\begin{tabular}{lccc}
\hline Parameter & \multicolumn{2}{c}{ Kribi Forest } & $\begin{array}{c}\text { Campo-Ma'am } \\
\text { National Park }\end{array}$ \\
\cline { 2 - 4 } & R. Kienke & R. Linde & R. Bitande \\
\hline Species richness & 22 & 20 & 47 \\
No. of Individuals & 38 & 48 & 108 \\
Shannon-Weiner H & 2.99 & 2.95 & 3.80 \\
Simpson (1-D) & 0.94 & 0.95 & 0.98 \\
Evenness E & 0.90 & 0.95 & 0.95 \\
\hline
\end{tabular}

Six species of Calopterygidae were recorded in this study. Five out the six species were collected at River Bitande (Phaon iridipennis, Sapho orichalea, S. gloriosa, S. ciliata and Umma longistigma), three species at River Kienke (Phaon cameroonesis P.iridipennis and Umma longistigma) and two at River Linde (Sapho orichalea and Umma longistigma). All the six species of Chlorocyphidae collected were found at the study sites except Chlorocypha neptuna which only occurred at River Bitande. Eight species of Coenagrionidae were recorded in this study, five of which belonged to genus
Pseudagrion while two species belonged to Agriocnemis and one to Africallagma.

\section{Discussion}

Rapid assessment programme has been a usual exercise conducted by International Union for the Conservation of Nature and Natural Resources (IUCN). In 2005 and 2007, rapid assessment programme on Odonata of Liberia and Ghana (respectively) was carried out by the organization (IUCN). The product of the assessment programme includes the discovery of Atoconeura luxata for the first time in Ghana and was listed among the regional threatened species by 
IUCN. Also a total of 93 species of Odonata were sampled in Liberia during a similar assessment programme at Gola and Grebo National, Forest Liberia. Dijkstra (2007a) concluded that rapid assessment programmes have the tendency to measure indirect anthropogenic disturbance.

The study area for this assessment programme (i.e. Southern Cameroon forests) may be considered rich in Odonata . It is important to mention here that more species of Odonata as well as high number of individuals could have been recorded, but for the short duration of survey. Also the visits to the forests were during the wet season, a period characterized by cloudy day and torrential rainfall. During this period, some riparian vegetation which could provide oviposition sites for mature reproductive females were submerged. Also this period is usually too dangerous for emerging teneral adults which could easily be flushed away by allochthonous run-off. The two monospecific families Aeshnidae and Lestidae (Gynacantha bullata and Lestes uncifer respectively) are forest species. Collecting them at Campo Ma'am National Park showed that anthropogenic activity in the forest was minimal, since Aeshnidae are generally shade lovers. It was not unexpected that $G$. bullata was collected at the river side since the species is generally known to inhabit streams and swamps in dense forests. $G$. bullata has a wide geographical distribution and has been reported to occur in forests of West Kenya, North Malawi and all over West Africa (Clausnitzer and Dijkstra, 2009).

All the species of Calopterygidae collected in this study are forest insects (Samways, 2008) whose range extends from Cote d'Ivoire to Cameroon Dijkstra and Clausnitzer, 2015). Vick (2009) had earlier reported that Chlorocypha neptuna is a rare species which only occurs in Cameroon in the whole of tropical Africa. The species was the only chlorocyphid species recorded in this study at one site, thus confirming its endemism in Cameroon and rarity in the whole of tropical Africa. Generally, Chlorocypha is endemic to tropical Africa with over 30 species. They are forest Odonata found to inhabit all manner of running waters from West Africa to Central Africa). Pseudagrion, which recorded the highest number of species among the coenagrionids in this study, is the largest genus in the family with almost a hundred species (Dijkstra, 2003). The five Pseudagrion species are widespread across West Africa and have been reported from Republic of Benin to Cameroon (Gambles, 1980) as well as East Africa (Clausnitzer and Dijkstra, 2005).

The three species of Corduliidae collected in this study belonged to genus Phyllomacromia (P.contumax, P. overlaiet and $P$. paula) and they were recorded only in Campo Ma'am National Park, at some distance from the river. Phyllomacromia is not new to Cameroon and its larvae have been part of the delicacy of people living around Mount Kupe (Vick, 1999). Only two species (Platycnemis rufipe and Mesocnemis singularis) of the Platycnemididae were recorded in this study. They have earlier been reported in Cameroon (Vick, 1999). Their distribution range includes Senegal, Ghana, Republic of Benin, Nigeria and Upper Guinean forests (Vick, 1998; Adu and Ogbogu, 2011).

Many of the libellulids collected are well known across West Africa. 
Orthetrum stemmale, $O$. brachiale and Trithemis arteriosa were well represented in all the study sites. Orthetrum stemmale had been reported in Guinea, Ivory Coast, Nigeria, Ghana and Ethiopia (Clausnitzer and Dijkstra, 2005; Adu and Ogbogu, 2011). Patala flavescens, Orthetrum julia and Trithemis arteriosa have also been recorded in Takamanda Forest Reserve, Cameroon (Vick, 2003).

\section{Conclusion}

In conclusion, it is obvious that the two forests are rich in odonate fauna, although Campo Ma'am National Park appears richer. Findings from this study have provided baseline information for odonatologists who may want to carry out research on dragonflies and damselflies of Kribi Forest and Campo Ma'am National Park. It is believed that a more elaborate study on the odonate fauna of the forests would record higher taxa richness. It is therefore recommended that a thorough survey be carried out in the two forests which should extend beyond the three rivers (R. Kienke, R. Linde and R. Bitande). Priority should be given to other natural water bodies such as streams, springs and swamps so that restricted and localized Odonata species hidden in the forests can be fully accounted for.

\section{Acknowledgement}

We appreciate Klaas-Douwe B. Dijkstra (KD) of the National Museum of Natural History Naturalis, Leiden, Netherlands for sponsoring the field trip of one of the authors and for the identification of all the specimens collected at the forests

\section{References}

Adu, B.W. and Ogunjobi, A.A. (2014). Assessment of dragonflies and damselflies of Owena Forest, Southwestern Nigeria. International Journal of AgriScience, 4(3): 153-159.

Adu, B.W. and Ogbogu, S.S. (2011). Diversity of Dragonflies and Damselflies (Insecta:Odonata) in Obafemi Awolowo University, IleIfe, Southwestern Nigeria. Agrion, 15(1): $24-31$.

Chelmick, D.G. (1999). Larvae of the genus Anax in Africa (Anisoptera:Aeshnidae). Odonatologica, 28(3): 209-218.

Chelmick, D.G. (2001). Larvae of the genus Aeshna Fabriciusin Africa south of the Sahara (Anisoptera: Aeshnidae). Odonatologica, 30(1): 39-47.

Che Salmah, M.R., Hassan, A.A. and Wahizatul, A.A. (2005). Preliminary study on the composition and distribution of Odonata in Perlis State Park. Malayan Nature Journal, 57(3): 317-326.

Clark, T.E. and Samways, M.J. (1994). An inventory of the damselflies and dragonflies (Odonata) of the Kruger National Park, with South Africa records. African Entomology, 2(1): 61-64.

Clausnitzer, V. (2006). Dragonflies (Odonata) of Rufiji District, Tanzania with new records for Tanzania. Journal of East African Natural History, 95(2):139-162.

Clausnitzer, V. and Dijkstra, K-D.B. (2005). The dragonflies (Odonata) of Ethiopia, with notes on the status of endemic taxa and the description of a new species. Entomologische 
Rapid Survey of Dragonflies (Insecta: Odonata) of Kribi Forest................ADU et al.

Zeitschrift $\cdot$ Stuttgart, 115(3): 117130.

Corbet, P.S. (1999). Dragonflies: behaviour and ecology of Odonata, Harley Books, Colchester.

Dijkstra, K-D.B. (2003). A review of the taxonomy of African Odonata finding ways to better identification and biogeographic insight. Cimbebasia, 18: 191-206.

Dijkstra, K-D.B. (2007). Dragonflies and Damselflies (Odonata) of the Atewa Range, Ghana. In A Rapid Biological Assessment of the Atewa Range Forest Reserve, Eastern Ghana, McCullough, J., Alonso, L.E., Naskrecki, P., Wright, H.E. and Osei-Owusu, Y. (eds). RAP Bull. Biol Assess. 47. Conservation International, Arlington, VA, 50-54.

Dijkstra, K-D.B. and Clausnitzer, V. (2015). The dragonflies and damselflies of eastern Africa: handbook for all Odonata from Sudan to Zimbabwe. Studies in Afrotropical Zool. Belgian Royal Museum for Central Africa Pensoft. 298

Karsch, F. (1890). Ueber Gomphidae. Ent.Nachr., 16: 370-382

Korkeamaki, E. and Suhonen, J. (2002). Distribution and habitat specialization of species affect local extinction in dragonfly Odonata populations. Ecography, 25: 459 465.

Mbuagbaw, T.E., Brain, R. abd Palmer, R. (1987). A history of the Cameroon. Second edition. Longman, Essex, UK

Pinhey, E.C.G. (1962). Some records of Odonata collected in tropical Africa. Journal of the
Entomological Society of South Africa, 25: 20-50.

Pinhey, E.C.G. (1964). Further records of African dragonflies (Odonata). Journal of the Entomological Society of South Africa, 26: 324336.

Pinhey, E.C.G. (1974). Order Odonata. In: W.G.H. Coaon, ed., Status of taxonomy of the Hexapoda of Southern Africa. Ent. Mem. Dept. agri. tech. Serv. Rep. Sth. Afr., 38: 17-19.

Samways, M.J. (2008). Dragonflies and damselflies of South Africa. Pensoft Sofia-Moscow. 298

Sarmistha, J., Priti, R., Tapan, P., Dutta, K. and Tanmay, B. (2009). Diversity and community structure of aquatic insects in a pond in Midnapore town, West Bengal, India J. Environ. Biol. 30(2): 283287

Shannon, C. (1948). A mathematical theory of communication. Bell Systems Technological Journal, 27:379-423.

Smith, K.G., Diop, M.D., Niane, M. and Darwall, W.R.T. (Compilers). (2009). The Status and Distribution of Freshwater Biodiversity in Western Africa Gland, Switzerland and Cambridge, UK : IUCN 108

Stewart, D.A.B. and Samways, M.J. (1998). Conserving dragonfly (Odonata) assemblages relative to river dynamics in a major African savanna game reserve. Conversation Biology, 12: 683-692.

Vick, G.S. (1998). Notes on some damselfly larvae from Cameroon (Zygoptera: Perilestidae, Amphipterygidae,

Platycnemididae). Odonatologica, 27: 87-98. 
Vick, G.S. (1999). A checklist of the dragonflies of the South West province of Cameroon, with a description of Phyllogomphus corbetae spec. nov. (Anisoptera: Gomphidae). Odonatologica, 28: 219-256.

Vick, G.S. and Clausnitzer, V. (2003). Dragonfly communities in coastal habitats of Kenya: indication of biotope quality and the need of conservation measures. Biodiversity and Conservation, 12: 333-356.

Watanabe, M., Matsuoka, M. and Taguchi, M. (2004). Habitat selection and population parameters of Sympetrum infuscatum (Selys) during sexual mature stages in a cool temperate zone of Japan (Anisoptera: Libellulidae). Odonatologica, 33: $169-179$. 